\title{
First Nations/Indigenous People's Wisdom
}

\author{
M. H. Saier Jr. • J. T. Trevors
}

Published online: 8 April 2008

(C) Springer Science + Business Media B.V. 2008

Ever since the white man entered the new world, invading and then destroying First Nations/Indigenous People's territories, Native Americans have been second class citizens. At first, they were considered savages, barely human. They were certainly not considered worthy of equal standing with the pale face. The real reason? Europeans brought with them awe-inspiring explosives, gun powder and violence (also religion and diseases). And they used them as dictated by their more violent natures. This allowed them to conquer and decimate indigenous populations shamelessly.

In spite of their power, achieved through violence, Europeans lacked the sense of responsibility to the Earth that had been a part of Native American cultures. Native Americans were our first true environmentalists. They had the knowledge - and the wisdom - that Americans from foreign countries are only now coming to appreciate. The great law of

M. H. Saier Jr. $(\bowtie)$

Division of Biological Sciences, University of California, La Jolla,

San Diego, CA 92093-0116, USA

e-mail: msaier@ucsd.edu

J. T. Trevors

Department of Environmental Biology,

University of Guelph,

Guelph, Ontario, Canada N1G 2W1

e-mail: jtrevors@uoguelph.ca the Iroquis Confederacy reads as follows: "In our every deliberation, we must consider the impact of our decisions on the next seven generations." The world would not have to face our current environmental crises if this law has been wisely followed by all people and countries.

To illustrate Native American wisdom, we shall examine the words of a few of the great Chiefs and other prominent Native Americans where voices have prevailed, if only in the almanacs. Below we cite some examples that illustrate their appreciation of the Earth's supportive biosphere. They provide guides for all walks of life, for all people, for a better world.

1. "Being Indian is an attitude, a state of mind, a way of being in harmony with all things and all beings. It is allowing the heart to be the distributor of energy on this planet; to allow feelings and sensitivities to determine where energy goes."-Brooke Medince Eagle

2. "If you talk to the animals they will talk with you and you will know each other. If you do not talk to them you will not know them and what you do not know, you will fear. What one fears, one destroys."-Chief Dan George

3. "We must protect the forests for our children, grandchildren and children yet to be born. We must protect the forests for those who can't speak for themselves: the birds, animals, fish and trees."-Qwatsinas (Hereditary Chief Edward Moody), Nulax Nation 
4. "I see a time when all the colors of mankind will gather under the Sacred Tree of Life, and the whole Earth will become one circle again."Crazy Horse, Sioux Chief

5. "The Earth is the Mother of all people, and all people should have equal rights upon it."-Chief Joseph, Nez Perce

6. "I was warmed by the sun, rocked by the winds and shaded by the trees. I am at one with Nature and can go everywhere with a good feeling."Geronimo, Apache

7. "A very great vision is needed, and the man who has it must follow it as the eagle seeks the deepest blue of the sky."-Crazy Horse, Sioux Chief

Proverbs that have been passed down for generations also reflect the First Nations' attitude towards Nature. They embody the conviction that humans are a part-a small part of nature. We must fit in rather than dominate if we are to preserve our heritage. This view and other tidbits of the Native American value systems reflect a quiet, reflective side of human nature.

1. "The frog does not drink up the pond in which he lives."-Sioux

2. "We are made from Mother Earth and we go back to Mother Earth"- Shenandoah

3. "We do not inherit the Earth from our Ancestors, we borrow it from our Children."-Tribe Unknown

4. "It is no longer good enough to cry peace, we must act peace, live peace and live in peace."Shenandoah

5. "When we show our respect for other living things, they respond with respect for us."Arapaho

6. "Force, no matter how concealed, begets resistance."-Lakota

7. "We will be known forever by the tracks we leave."-Dakota
Now compare the Native American Ten Commandments with those that Moses brought down from the mountains.

1. Treat the Earth and all that dwell therein with respect

2. Remain close to the Great Spirit

3. Show great respect for your fellow beings

4. Work together for the benefit of all Mankind

5. Give assistance and kindness wherever needed

6. Do what you know to be right

7. Look after the well-being of Mind and Body

8. Dedicate a share of your efforts to the greater Good

9. Be truthful and honest at all times

10. Take full responsibility for your actions

Whose directives do you prefer? Which philosophy can lead to a better, more responsible world order? What has been destroyed can never be replaced. But maybe we can learn from the wisdom of the people we forcibly replaced and acted against in such a cruel, violent, barbaric, discriminating and inhumane manner.

The First Nations displayed immense wisdom and clearly understood Article 1 (and likely the other Articles, 30 in total) in The Universal Declaration of Human Rights, United Nations General AssemblyAll human beings are born free and equal in dignity and rights. They are endowed with reason and conscience and should act towards one another in a spirit of brotherhood. How did the European invaders rationalize any of their cruel actions using religion, economics, outright discrimination and genocide? There is no acceptable rationalization for their actions. To the victors go the spoils. How barbaric!

The wisdom of the First Nations could have aided all humans in preventing the global disaster we are now facing: too many humans, too much waste, global warming, immense poverty and shortages of natural resources including food and fuel. 